University for Business and Technology in Kosovo

UBT Knowledge Center

UBT International Conference

2016 UBT International Conference

Oct 28th, 9:00 AM - Oct 30th, 5:00 PM

\title{
Green Energy or Nuclear Power Plants
}

\author{
Besnik Skenderi \\ University for Business and Technology, besnik.skenderi@ubt-uni.net \\ Diamanta Skenderi \\ University for Business and Technology
}

Follow this and additional works at: https://knowledgecenter.ubt-uni.net/conference

Part of the Engineering Commons, and the Physical Sciences and Mathematics Commons

\section{Recommended Citation}

Skenderi, Besnik and Skenderi, Diamanta, "Green Energy or Nuclear Power Plants" (2016). UBT International Conference. 39.

https://knowledgecenter.ubt-uni.net/conference/2016/all-events/39

This Event is brought to you for free and open access by the Publication and Journals at UBT Knowledge Center. It has been accepted for inclusion in UBT International Conference by an authorized administrator of UBT Knowledge Center. For more information, please contact knowledge.center@ubt-uni.net. 


\title{
Green Energy or Nuclear Power Plants
}

\author{
Besnik Skenderi, Diamanta Skenderi \\ UBT - Higher Education Institution, Lagjja Kalabria, 10000 p.n., \\ Prishtine, Kosovo \\ besnik.skenderi@ubt-uni.net
}

\begin{abstract}
World seems to go green regarding the energy, however the cost of green energy is high and as a result of security issues nuclear energy seems to be avoided, while introducing business and outsourcing concepts nuclear energy seems to be solution.
\end{abstract}

Keywords: Energy, Environment, Shareholders, Outsourcing

\section{Introduction}

Since introduction of vapor machines, need for energy is permanent and this need is increasing every day. Despite the fact that technology is changing and new innovation had taken place, transfer of energy still is going through copper vires and main sources for

\section{What is energy?}

Energy makes change possible. Energy moves cars along the road and boats through the water. Energy bakes a cake in the oven, keeps ice frozen in the freezer, and lights homes.

Scientists define energy as the ability to do work. Modern civilization is possible because people have learned how to change energy from one form to another and then use it to do work.

Forms of energy

There are many forms of energy, but they can all be put into two categories:

- $\quad$ Potential energy

- Kinetic energy

\begin{tabular}{|c|c|c|}
\hline \multicolumn{3}{|c|}{ Overview of each major energy source's impact on the environment } \\
\hline $\begin{array}{l}\text { Nonrenewable energy sources } \\
\text { - Coal } \\
\text { " Natural gas } \\
\text { " Nuclear } \\
\text { " Oil and petroleum products } \\
\text { " Gasoline } \\
\text { " Diesel fuel }\end{array}$ & $\begin{array}{l}\text { Renewable energy sources } \\
\text { " Biodiesel } \\
\text { " Biomass } \\
\text { " Ethanol } \\
\text { " Geothermal } \\
\text { " Hydropower } \\
\text { " Solar } \\
\text { " Wind }\end{array}$ & $\begin{array}{l}\text { Secondary energy sources } \\
\text { " Electricity }\end{array}$ \\
\hline
\end{tabular}


Book of Proceedings

International Conference on Mechatronics, Sciences in Energy Efficiency Engineering,

System Engineering and Robotics

\section{Sources of energy}

During the process of evolution human beans had face with need for different sources of the energy, in a last century in a world experts had developed and implement several technologies for this purpose. (Mandil) is stating that "Technologies can make a difference, .... A sustainable energy future is possible, but only if we act urgently and decisively to promote, develop and deploy a full mix of energy technologies - We have the means, now we need the will" Among those technologies are:

a) Nuclear power plants

b) Coal-fired power plants

c) Hydro-power plants

d) Wind Power

Each of above mentioned technologies have its problem and benefits and most common thing regarding those technologies is that all of them need skilled and well trained people and all of them are having negative impact in the environment.

\section{Nuclear power plants}

Since the middle of the last century nuclear power plants are used to produce electricity. Strengths of using this technology are that the benefits exceed its cost and according (Bruno) "one nuclear plant cover the needs of several millions people". This technology it is not contributing in $\mathrm{CO}_{2}$ emission. This technology is having also its problems. The main problem for nuclear plants still is remaining nuclear waste and as other problem is that of long lead time for construction and public safety perception regarding nuclear power plants.

The United States imports most of the uranium it uses as fuel, in addition owners and operators of U.S. nuclear power reactors purchased the equivalent of 56.6 million pounds of uranium in 2015 . Only $6 \%$ of the uranium delivered to U.S. reactors in 2015 was produced in the United States and $94 \%$ came from other countries:

- $\quad 37 \%$ from Kazakhstan, Russia, and Uzbekistan

- $\quad 30 \%$ from Canada

- $17 \%$ from Australia

- $10 \%$ from Malawi, Namibia, Niger, and South Africa

\subsection{Coal-fired power plants}

Coal fired power plants are using follies like coil, in order to produce electricity. Those plants are contributing in global warming, according (RIT) "global surface temperature increased $0.74 \pm 0.18{ }^{\circ} \mathrm{C}$ $\left(1.33 \pm 0.32^{\circ} \mathrm{F}\right)$ between the start and the end of the 20th century". Also mining is difficult and dangerous process as well. Coal fired power plants need to have extra spare quantity of coils in order to fulfill customer demands for electricity.

Benefits from use of this technology are that Coal fired power plants can be built everywhere where it is possible to transport coil and those power plants can produce large quantity of electricity. 


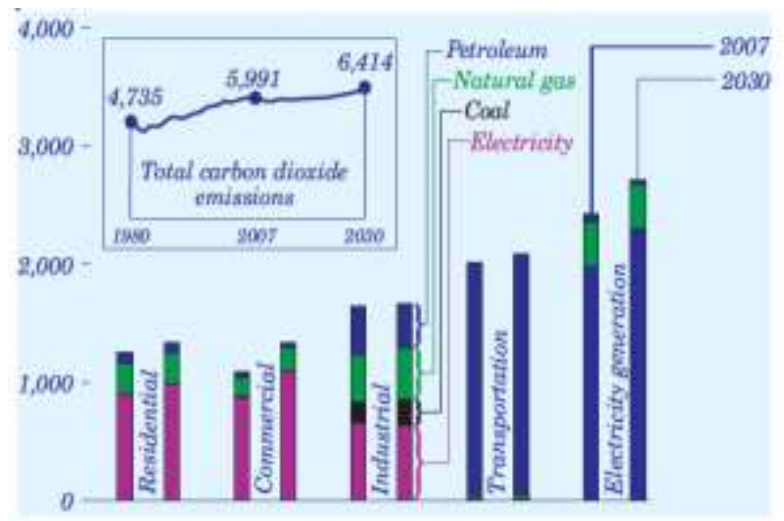

Figure. 1, Carbon dioxide emissions by sector and fuel, 2007 and 2030 (million metric tons)

\subsection{Hydro-power plants}

Regarding hydrogen economy (Veer) is stating that :"even given the most optimistic scenario for hydrogen, it may take another 40 years before hydrocarbons fully lose their dominance of the energy industry" but despite this fact according (wikipedia) 19\% of electrical energy in a world is produced by hydro power plants. Advantages of this technology are that with this technology there is no waste or pollution, this technology is more reliable than solar or wind power and hydro-power plants may enlarge to full power very quickly. While problems which are opposing this technology are that the dams are large investments and building a large dam could flood large areas of land which will cause change in eco system and also it may reduce quality of water.

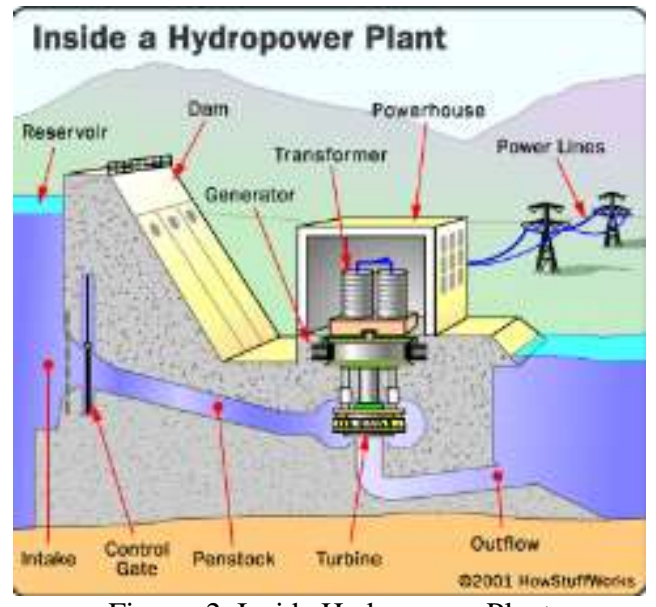

Figure. 2, Inside Hydropower Plant 
Book of Proceedings

International Conference on Mechatronics, Sciences in Energy Efficiency Engineering,

System Engineering and Robotics

\subsection{Wind Power}

Electricity is produced also from wind with use of turbines, which are very expensive and in a same time require a specific and expensive maintenance. Those turbines are making noise and taking lot of space and they are not convenient for urban areas. But there are also benefits from using this technology to produce electricity. Only in Europe during the year 2009, emission of 91 million tons of $\mathrm{CO} 2$ is avoided with use of this technology (EWEA). Another benefit from implementing this technology is that wind is free so in order to produce electricity this technology is not burning any fossils at all.

\subsection{The significance of needs of the US Navy and the perception of safety by the US general Public}

(Morone and Woodhouse) Are stating that: "The scale-up and shift in safety strategy represented a critical juncture in the history of nuclear power". All this had started with introduction of light water reactors which are used in US navy submarines. Because of the circumstances, US navy had selected an economical reactor and didn't focus too much at safety. This was because in that time was only one military approach, and civilian or commercial approach to this issue was low. US navy was focused on creating economic reactors and their goal was to use those reactors in submarines. In the other way civilian sector had its concerns regarding inherent safety. (Morone and Woodhouse).

If reactor developers had focused in safety of reactors as they were focused in economical aspect today, we would have safe reactors which would work with minimal risks. Some initiatives had existed regarding this, for example in 1956 General Atomic had produced TRIGA (Training/Research/Isotopes/General Atomic) safe reactor which was distributed in hospitals, universities and institutions. But TRIGA reactors had had short product life because they didn't have large capacity for producing electricity.

One decade later reactor producer had start to see the possibility of commercial use of nuclear reactors and for the first time they had started to think and to focus on safety issues. But all researches regarding safety were done on low capacity reactors (100 megawatts or less) and commercial reactors had had capacity from $100-300$ megawatts. This had increase perception of safety by the US general public and if in that time reactor manufactures would focus more on safety today we could have different nuclear reactors and in general this technology would have different path of development.

(Morone and Woodhouse) As a characteristic of the American nuclear enterprise are identifying facts that it is based on competitive privately owned supplier industry. Because of this many companies had ordered nuclear reactors and then they had sold electricity to other companies or directly to their customers. But if we had had the case were nuclear power plants where publicly owned, development of this industry would have different path not only in the US but also in a world. Instead of having many small reactors in the US would exists couple of large reactors and there would be the risk of malfunctioning because in that time this was new technology. In the other way this would help standardization of this technology within US. For example, in US were four manufactures, each with different design and twelve architect-engineering firms competing and multiple sizes and periodically updated designs from each manufacturer.

If this technology was standardized than there will not be the cases where companies are ordering reactors and they don't have required skills and training to operate with those reactors and in a same time, there will be share of experience between companies which are within the same industry. 
There was a series of protests held over the world to demand their governments to abandon the nuclear power since the Fukushima crisis. Media kept broadcasting previous accidents such as Ukraine's Chernobyl and the Three Mile Island accident in the United States. The public is increasingly afraid of another nuclear disaster and magnifies perception of risk toward nuclear energy. Despite the Japan accident, some countries (e.g. France, Korea, China) still regard nuclear power as a carbon-free energy source and approve of it.

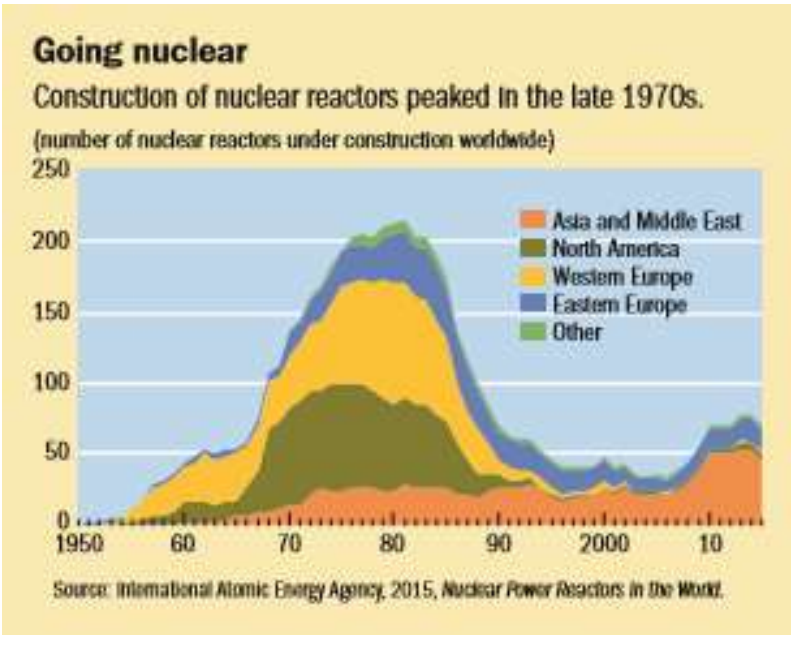

Davis and Hausman (2015) But it still won't be easy for nuclear power. In addition to high construction costs, nuclear power faces other significant challenges. In North America, for example, natural gas is so cheap it makes it hard to justify any other type of power plant. You can build a nuclear plant and sell electricity around the clock, but still not make enough profit to pay for the plant

\section{Nuclear electricity generation by top 10 countries, 2014 billion kilowatthours}

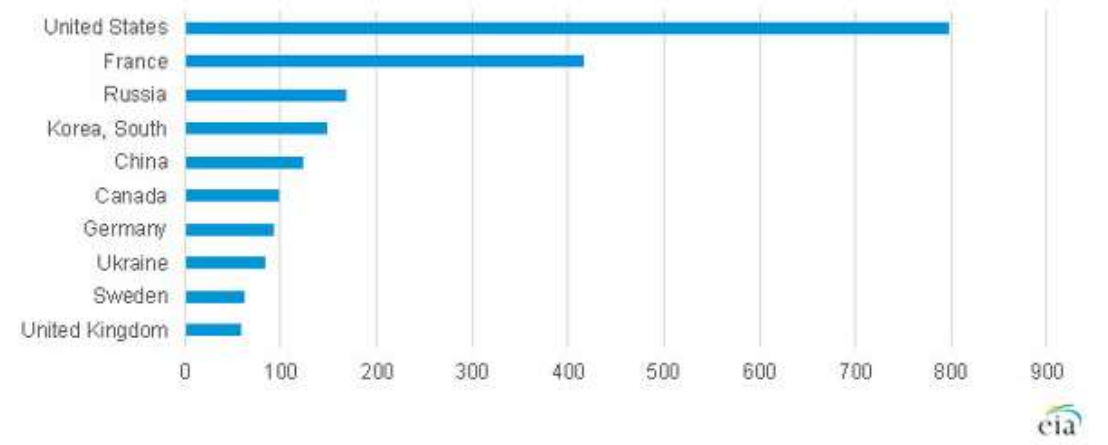

Source: U.S. Energy Information Administration 
Book of Proceedings

International Conference on Mechatronics, Sciences in Energy Efficiency Engineering,

System Engineering and Robotics

\section{Conclusions}

As well as the impact of the size of the nuclear plant, location might also impact on efficiency by attracting consumption and lowering the cost of transportation of the energy.

\section{References}

1. Andriamasy, L, Barros, C, \& Liang, Q 2014, 'Technical efficiency of French nuclear energy plants', Applied Economics, 46, 18, pp. 2119-2126, Business Source Complete, EBSCOhost, viewed 27 July 2016.

2. Bruno, Pellaud. http://icapp.ans.org. 14 May 2007. 31 January 2010. <http://icapp.ans.org/icapp07/MONDAY/Opening/ICAPP-Pellaud.doc.>.

3. Chu-Ching, W, Yueh-Hua, L, \& Yu-Min, W 2014, 'Measuring The Social Value Of Nuclear Energy Using Public Involvement In Public Management', International Journal Of Business \& Public Administration, 11, 2, pp. 23-36, Business Source Complete, EBSCOhost, viewed 27 July 2016.

4. Davis, L, \& Hausman, C 2015, 'Power of the Atom', Finance \& Development, 52, 4, pp. 18-19, Business Source Complete, EBSCOhost, viewed 27 July 2016.

5. de Groot, J, Steg, L, \& Poortinga, W 2013, 'Values, Perceived Risks and Benefits, and Acceptability of Nuclear Energy', Risk Analysis: An International Journal, 33, 2, pp. 307-317, Business Source Complete, EBSCOhost, viewed 27 July 2016.

6. DOE/IEA. http://www.eia.doe.gov. March 2009. 31 January 2010. <http://www.eia.doe.gov/environment.html>.

7. EIA. http://www.eia.doe.gov. 2006. 31 January 2010. <http://www.eia.doe.gov/emeu/international/electricitygeneration.html>.

8. emt. http://www.emt-india.net. 2001. 31 January 2010. <http://www.emtindia.net/process/power_plants/Hydro_power.htm>.

9. EWEA. http://www.ewea.org. 2009. 31 January 2010. <http://www.ewea.org/index.php?id=180>.

10. Mandil, Claude. http://www.eia.doe.gov. 22 June 2006. 31 January 2010. <http://www.eia.doe.gov/cneaf/nuclear/page/nuc_reactors/reactsum.html>.

11. Morone, Joseph G and Edward J Woodhouse. "Paths not Taken." The Demise of Nuclear Energy? Yale University Press, n.d. 104-117.

12. RIT- Generation Technology \& Economics. Prishtina, January 2010. 